\title{
The effect of dietary protein on reproduction in the mare. V. Endocrine changes and conception during the early post partum period
}

\author{
F E van Niekerk ${ }^{\mathrm{a}}$ and $\mathrm{C} \mathrm{H}$ van Niekerk ${ }^{\mathrm{a}}$
}

\begin{abstract}
Pregnant Anglo-Arab and Thoroughbred mares $(n=24)$ were divided randomly according to age and breed into 4 groups of 6 mares each from approximately 6 weeks before their expected foaling date. Diets received by the 4 groups varied in essential amino-acid and total protein contents. Serum progestagen, FSH and LH concentrations were determined from the day of parturition until foal heat and during the 1st oestrous cycle following foal heat. Serum progestagen, FSH and LH concentrations did not differ between the treatment groups. Progestagen concentrations were high $(\bar{x}=7.0: 5.2-16.4 \mathrm{ng} / \mathrm{m} \ell)$ at parturition but decreased rapidly within $48 \mathrm{~h}$. As progestagen concentrations decreased LH concentrations increased from Days 3-6 post partum to reach maximum values at, or the day after ovulation. FSH concentrations declined 3-4 d after parturition and increased 2-3 d before ovulation at foal heat. The duration of elevated progestagen concentrations during the luteal phase of the subsequent oestrous cycle affected the interovulatory period. A 12-14 d FSH cyclical releasing pattern occurred. Season/photoperiod affected the resumption of normal oestrous cyclicity during the post partum period. The duration of the 1st oestrous cycle after foal heat in mares fed a low-quality protein diet showed a greater range (13-30 d) compared to mares fed a high-quality protein diet (18-26 d).
\end{abstract}

Key words: equine, FSH, LH, post partum period, protein nutrition, serum progestagens.

Van Niekerk F E, Van Niekerk C H The effect of dietary protein on reproduction in the mare. V. Endocrine changes and conception during the early post partum period. Journal of the South African Veterinary Association (1998) 69(3): 81-88 (En.). Department of Human and Animal Physiology, University of Stellenbosch, Private Bag X1, Matieland, 7602 South Africa.

\section{INTRODUCTION}

The duration of pregnancy of $c .11$ months in the Thoroughbred mare implies that the mare must reconceive within 30 days post partum in order to produce a foal each year. The post partum interval is described as the time after parturition when the uterus undergoes involution to the state where pregnancy can be maintained ${ }^{14}$. Late pregnancy, parturition and the early post partum period are characterised by major changes in the reproductive and endocrine systems $^{32}$.

Foal heat occurs within 7-9 d of parturition in more than $90 \%$ of mares ${ }^{4,8,19,31}$. Although mares will ovulate and conceive during foal heat ${ }^{1,6}$, several studies indicated a reduced pregnancy rate ${ }^{4,28}$ and embryonic loss that may be associated with the actual state of the uterine environment ${ }^{14}$.

\footnotetext{
${ }^{a}$ Department of Human and Animal Physiology, University of Stellenbosch, Private Bag X1, Matieland, 7602 South Africa.
}

Received: December 1997. Accepted: June 1998.
The reproductive efficiency of lactating mares is affected by both season/photoperiod and nutrition. Approximately $28 \%$ of Thoroughbred mares that foal early in spring do not show signs of oestrus ${ }^{30}$. Optimal energy intake of lactating mares is important because this is the period when reconception should take place ${ }^{7}$. The bodily condition of the mare at foaling is therefore important, as mares in poor condition at foaling may maintain that condition at the expense of milk production $^{17}$. Conception is improved when mares are maintained in a positive energy balance during lactation ${ }^{25,37}$ and by limiting the period of suckling by the foal $^{16}$. Studies have indicated that a protein deficiency in the diet might contribute to early embryonic loss irrespective of the mare's bodily condition $^{5,38}$.

The purpose of this study was to determine the normal clinical, morphological and endocrine changes that occur in the reproductive functions of the mare during the post partum period until reconception. The effects of season at the time of foaling and dietary protein quality and intake were also investigated.

\section{MATERIALS AND METHODS}

Pregnant Thoroughbred and AngloArab mares $(n=24)$ were kept on pasture until 6 weeks before their expected foaling dates and were then allocated randomly according to age and breed to 1 of 4 dietary groups of 6 mares each. The 4 diets consisted of: Group 1: tef hay $(6 \mathrm{~kg})$ and cubes $(4 \mathrm{~kg})$; Group 2: lucerne hay $(6 \mathrm{~kg})$ and cubes $(4 \mathrm{~kg})$; Group 3: tef hay $(4 \mathrm{~kg})$, cubes $(6 \mathrm{~kg})$ and fishmeal (200 g); Group 4: lucerne hay $(6 \mathrm{~kg})$, cubes $(4 \mathrm{~kg})$ and fishmeal $(200 \mathrm{~g})$. These 4 feeding regimens were chosen to obtain a wide range of dietary amino-acid contents. Tef hay is generally used as a source of roughage in large parts of South Africa. Its protein content is low compared to lucerne hay ${ }^{34}$. The crude protein and amino-acid intake of mares in the different dietary groups has been described $^{35}$. The cubes were offered in 2 equal portions in the morning and afternoon $^{35}$. After the mares had foaled, the cubes were increased to $6 \mathrm{~kg}$ fed 3 times a day in equal portions and the hay to $7 \mathrm{~kg}$, while the fishmeal remained at $200 \mathrm{~g} /$ day. Each mare and foal received their cubes separately, but during the morning feed, when the mares received their fishmeal, the foals were prevented from eating with the mares. Throughout the trial the mares finished all feed offered to them every day. At 3 months of age the foals received $1 \mathrm{~kg}$ of cubes and c. $2 \mathrm{~kg}$ of roughage per day. Each group of mares was kept in a $30 \times 50 \mathrm{~m}$ paddock. The foaling date was recorded in all cases.

Daily teasing commenced $2 \mathrm{~d}$ after parturition and continued until $90 \mathrm{~d}$ of pregnancy. The ovaries of the mares in oestrus were palpated daily. The ovaries of mares that had not shown signs of oestrus by $10 \mathrm{~d}$ post partum were palpated weekly until signs of oestrus became evident. During examinations the size and consistency of the ovaries and follicles present were determined as described previously ${ }^{36}$. A Squibb Model 2000 scanner with a $5 \mathrm{MHz}$ probe was 
Table 1: Comparison of the mean duration (days) from parturition to 1st oestrus and ovulation and the following oestrous period and follicular size $(\mathrm{mm})$ during both ovulations after parturition in mares in 4 dietary groups.

\begin{tabular}{|c|c|c|c|c|c|}
\hline \multirow[t]{2}{*}{ Oestrous cycle } & \multicolumn{4}{|c|}{ Dietary groups } & \multirow{2}{*}{$\begin{array}{l}\text { Mean } \\
\text { total }\end{array}$} \\
\hline & 1 & 2 & 3 & 4 & \\
\hline \multicolumn{6}{|l|}{ 1st oestrus } \\
\hline Number of mares & 6 & $4(5)$ & 4 & $5(6)$ & 19 \\
\hline Days from parturition to 1 st oestrus & $7.0 \pm 3.3$ & $\begin{array}{c}8.3 \pm 1.5 \\
(26.2 \pm 35.8)^{a}\end{array}$ & $9.7 \pm 2.9$ & $\begin{array}{c}10.0 \pm 3.5 \\
(19.0 \pm 20.3)^{a}\end{array}$ & $8.7 \pm 3.1$ \\
\hline Days in oestrus & $8.8 \pm 3.7$ & $5.0 \pm 2.4$ & $4.3 \pm 0.9$ & $5.3 \pm 1.9$ & $6.1 \pm 3.0$ \\
\hline Days from onset of oestrus to ovulation & $7.3 \pm 3.4$ & $3.5 \pm 1.7$ & $3.3 \pm 0.9$ & $3.8 \pm 2.3$ & $4.7 \pm 2.8$ \\
\hline Days from parturition to 1 st ovulation & $14.1 \pm 3.5$ & $\begin{array}{c}10.7 \pm 3.0 \\
(29.2 \pm 37.2)^{a}\end{array}$ & $12.8 \pm 4.1$ & $\begin{array}{c}14.0 \pm 5.6 \\
(22.5 \pm 21.4)^{a}\end{array}$ & $13.2 \pm 4.1$ \\
\hline \multicolumn{6}{|l|}{ Size of follicle $(\mathrm{mm})$} \\
\hline Onset of oestrus & $23 \pm 7.5$ & $27 \pm 2.9$ & $23 \pm 6.3$ & $24 \pm 5.8$ & $24 \pm 5.8$ \\
\hline Day before ovulation & $35 \pm 7.3$ & $36 \pm 9.5$ & $36 \pm 7.5$ & $37 \pm 5.2$ & $36 \pm 6.7$ \\
\hline \multicolumn{6}{|l|}{ 2nd oestrus } \\
\hline Number of mares & 5 & 3 & 4 & 4 & 16 \\
\hline Days in oestrus & $5.8 \pm 3.7$ & $3.7 \pm 1.5$ & $6.2 \pm 1.7$ & $6.8 \pm 1.7$ & $5.7 \pm 2.5$ \\
\hline Days from onset of oestrus to ovulation & $5.0 \pm 3.7$ & $3.7 \pm 1.5$ & $5.2 \pm 1.2$ & $5.5 \pm 2.4$ & $4.9 \pm 2.4$ \\
\hline \multicolumn{6}{|l|}{ Size of follicle $(\mathrm{mm})$} \\
\hline Onset of oestrus & $28 \pm 6.0$ & $22 \pm 10.0$ & $30 \pm 5.0$ & $26 \pm 11.0$ & $28 \pm 6.0$ \\
\hline Day before ovulation & $36 \pm 4.0$ & $35 \pm 5.0$ & $41 \pm 3.0$ & $42 \pm 3.0$ & $39 \pm 5.0$ \\
\hline Number of oestrous cycles & 7 & 9 & 3 & 4 & \\
\hline Mean duration of oestrous cycles (days) & 20.7 & 19.2 & 24.0 & 23.0 & 20.8 \\
\hline Range (days) & $16-31$ & $13-22$ & $22-28$ & $21-26$ & $13-31$ \\
\hline
\end{tabular}

${ }^{a}$ Mares that did not show oestrus within 20 days of parturition.

used for all ultrasonographic examinations.

Mares were mated during the 1 st oestrus following foal heat. If a mare did not show signs of oestrus within $12 \mathrm{~d}$ post partum she was mated during the 1st oestrous period. Mares were mated when a $30-50 \mathrm{~mm}$, soft, thin-walled follicle was palpable and daily thereafter until ovulation occurred, after which mating ceased.

Blood samples were collected on the day of parturition and every 2nd day thereafter until signs of oestrus were evident. Samples were collected daily during oestrus, and then every 3rd day until the following oestrous period. This procedure was followed until pregnancy was diagnosed. Blood samples were collected and the serum stored as described previously ${ }^{37}$.

All mares and foals were weighed on the day of foaling and weekly thereafter until the foals were weaned at 6 months.

\section{Hormone assays}

Total unconjugated serum progestagen

Serum samples were analysed for total unconjugated progestagens. The radio-immunoassay procedure was principally as described by Youssefnejadian et al. ${ }^{40}$ using an antibody generated in sheep according to the method of Odell et al. ${ }^{24}$ against $11 \alpha$-hydroxyprogesterone hemi-succinate BSA $^{12}$ as modified by Faure $^{10}$. In addition, the antibody shows significant cross-reactivity with $\alpha$-pregnane-3.20 dione, and to a much lesser extent with other pregnane derivatives of progesterone that are known to occur in the pregnant mare ${ }^{18}$. Cross-reactivity with major adrenocortical C18 and C19 steroids is for all practical purposes nonexistent $t^{33}$.

\section{Follicle-stimulating hormone (FSH)}

FSH concentrations were determined using the Amerlex-M FSH (Code DM 3070/3071) kit (Amersham, UK). Use of this antibody was based on the results of Alexander et al. ${ }^{2}$.

\section{Luteinising hormone ( $\mathrm{LH}$ )}

$\mathrm{LH}$ concentrations were determined using the method described by Niswender et al $^{23}$ as modified by Visser ${ }^{39}$.

\section{Statistical analysis}

Analysis of variance was conducted using the LSML 76 computer programme ${ }^{15}$.

\section{RESULTS}

The mean body weight of mares on the day of foaling was: Group 1, $437 \mathrm{~kg}$; Group 2, 472 kg; Group 3, 441 kg; Group $4,454 \mathrm{~kg}$. The mean birth weight of the foals of the mares in each group was:
Group 1, 47.3 kg; Group 2, 47.2 kg; Group $3,51.2 \mathrm{~kg}$; Group 4, $46.2 \mathrm{~kg}$.

The number of days from parturition until 1st signs of oestrus (foal heat), the duration of the oestrus periods, time of ovulation, diameter of follicles and the duration of the oestrous cycle following foal heat are shown in Table 1 for the lactating mares in the 4 dietary groups. The results that include the 2 mares (No. 8 in Group 2 and No. 20 in Group 4) that did not show signs of foal heat or oestrus until $80 \mathrm{~d}$ and $64 \mathrm{~d}$ post partum respectively, are shown separately in Table 1.

No differences in the diameter $(\mathrm{mm})$ of the largest follicle at the onset of oestrus and the diameter of the largest follicle on the day before ovulation were found between groups.

In Table 2 a comparison is made between the onset of 1st signs of oestrus and the time of ovulation in mares that foaled during August and September (transitional period) and mares that foaled during October to December (physiological breeding season), irrespective of their nutritional group. Those that foaled in the transitional period showed the 1st signs of oestrus on average $24 \mathrm{~d}$ post partum, compared to $9 \mathrm{~d}$ in those that foaled in the physiological breeding season, and on average the 1st ovulations occurred $27.1 \mathrm{~d}$ and $14.6 \mathrm{~d}$ post partum 
Table 2: Comparison of the mean number of days from parturition until the first signs of oestrus in mares that foaled early in the season (August - September) and mares that foaled later in the season (October - December).

\begin{tabular}{|c|c|c|c|c|c|c|}
\hline \multirow[t]{2}{*}{ Date of foaling } & \multirow{2}{*}{$\begin{array}{l}\text { Number } \\
\text { of mares }\end{array}$} & \multirow{2}{*}{$\begin{array}{l}\text { Days from foaling } \\
\text { to } 1 \text { st oestrus }\end{array}$} & \multirow{2}{*}{$\begin{array}{l}\text { Days from foaling } \\
\text { to } 1 \text { st ovulation }\end{array}$} & \multirow{2}{*}{$\begin{array}{l}\text { Duration of } 1 \text { st } \\
\text { oestrous period }\end{array}$} & \multicolumn{2}{|c|}{ Diameter of follicle $(\mathrm{mm})$} \\
\hline & & & & & At onset & At ovulation \\
\hline 14 Aug -28 Sept & 8 & $\begin{array}{l}24.0 \pm 30.0 \\
\quad(5-80)\end{array}$ & $\begin{array}{l}27.1 \pm 30.2 \\
\quad(6-64)\end{array}$ & $\begin{array}{l}5.1 \pm 2.6 \\
(2-9)\end{array}$ & $\begin{array}{l}25 \pm 5.0 \\
(15-30)\end{array}$ & $\begin{array}{l}38 \pm 7.0 \\
(30-50)\end{array}$ \\
\hline 4 Oct - $15 \mathrm{Dec}$ & 12 & $\begin{array}{c}9.0 \pm 3.5 \\
(4-14)\end{array}$ & $\begin{array}{c}14.6 \pm 3.2 \\
(8-19)\end{array}$ & $\begin{array}{c}6.8 \pm 3.2 \\
(4-14)\end{array}$ & $\begin{array}{l}24 \pm 6.0 \\
(10-30)\end{array}$ & $\begin{array}{l}35 \pm 6.0 \\
(25-40)\end{array}$ \\
\hline
\end{tabular}

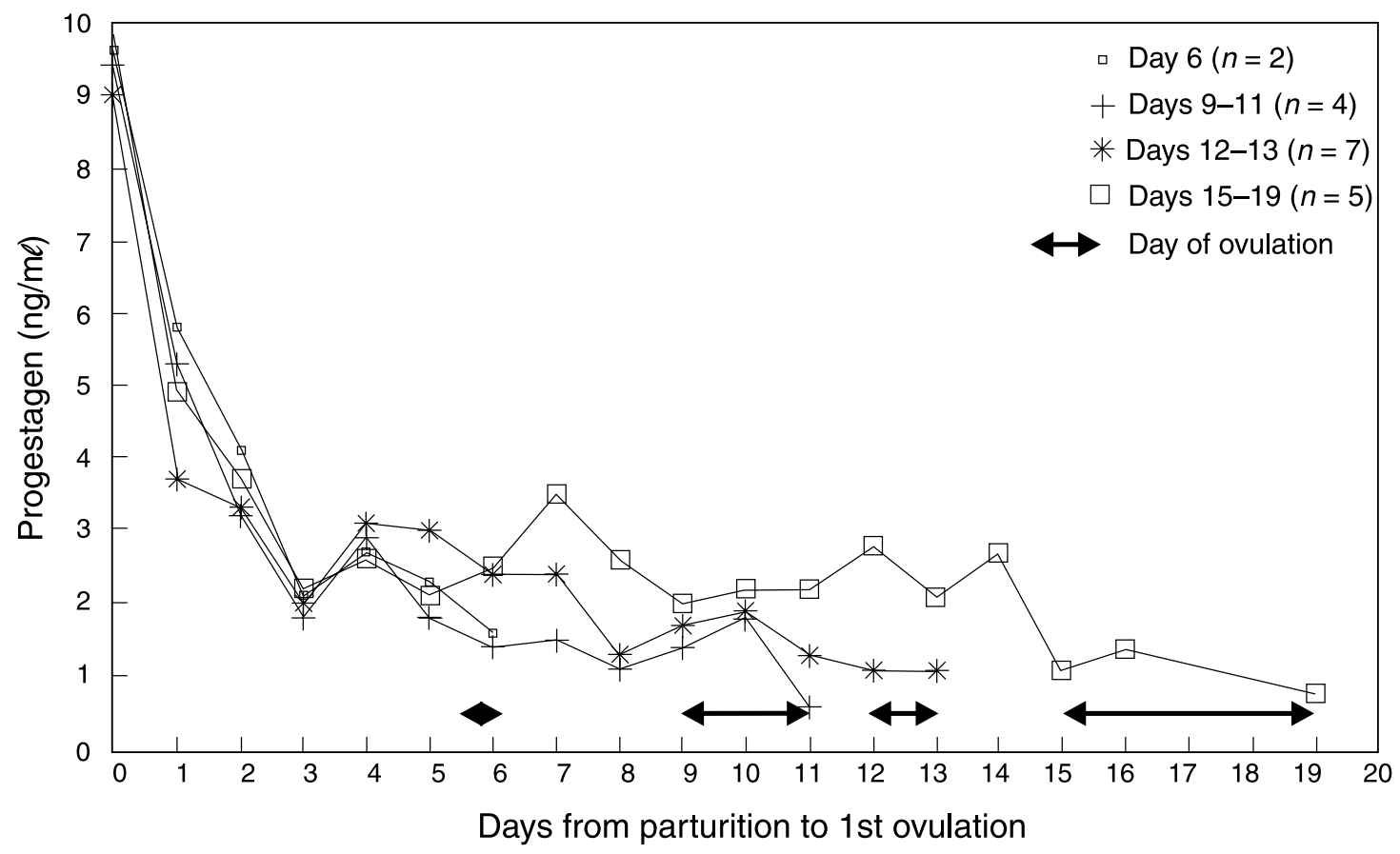

Fig. 1: Four mean serum progestagen concentration $(\mathrm{ng} / \mathrm{ml})$ patterns identified from parturition to ovulation at foal heat: Days 6, 9-11, 12-13 and 15-19.

respectively. The mean duration of the 1 st oestrous period for the early and late foalers was $5.1 \mathrm{~d}$ and $6.8 \mathrm{~d}$ respectively.

No differences in serum progestagen concentrations were found during the time from parturition to foal heat among the 4 nutritional groups. The mean serum progestagen concentrations of mares $(n=$ 18) that ovulated on Days 6, 9-11, 12-13 and 15-19 post partum are shown in Fig. 1.

The progestagen concentrations of mares during the 1st oestrous cycle after foal heat did not differ between the nutritional groups, and therefore the results of mares in all 4 dietary groups were pooled. During foal heat, serum progestagen concentrations increased within 2 days post-ovulation. Serum progestagen concentrations were $7-20 \mathrm{ng} / \mathrm{ml}$ at $4-6$ days post-ovulation and were maintained at these concentrations for 13-15 days, after which they decreased to reach baseline values $c$. 2 days before the next ovulation. After pooling the results, 4 different patterns of progestagen secretion were identified according to the duration of the interovulatory period, namely A: $17-19 \mathrm{~d}$; B: $20-22 \mathrm{~d}$; C: $24-25 \mathrm{~d}$, and D: $29-30 \mathrm{~d}$ (Fig. 2).

Persistent CLs were identified in 2 mares. Mare No. 8 (Group 2: lucerne hay and cubes), which foaled in mid-August, ovulated on Day 9 post partum without showing signs of oestrus for the following 80 days and had low $(<5 \mathrm{ng} / \mathrm{m} \ell)$ serum progestagen concentrations during this period (Fig. 3). Mare No. 20 (Group 4: lucerne hay, cubes and fishmeal), which foaled in September, showed no signs of oestrus but ovulated on Day 11 post partum. She then maintained low $(<5 \mathrm{ng} / \mathrm{ml})$ serum progestagen concentrations until signs of oestrus and she ovulated on Day 66 post partum (Fig. 3).

Serum LH and FSH concentrations were established only in mares in Group 1 (lowest quality protein) and Group 4 (highest quality protein), from parturition until foal heat and the following oestrous cycle until after ovulation. No differences in the LH concentrations between dietary groups that could be attributed to protein nutrition were found, and therefore the results were pooled to demonstrate the general secretion pattern. The mean pooled LH and progestagen concentrations from parturition until after the 2nd ovulation are shown in Fig. 4. The mean duration from foaling to ovulation at foal heat was $13.7 \mathrm{~d}$. LH concentrations increased gradually from Day 6 post partum until 2 days before ovulation, when the LH concentrations began to peak. In 11 of the 18 mares the LH peak occurred on the day of ovulation, and in the remaining 8 during the following day. $\mathrm{LH}$ concentrations decreased to baseline levels within $48 \mathrm{~h}$ post-ovulation.

The serum FSH concentrations were pooled, as no differences were found between mares in the 4 dietary groups from parturition to 1st ovulation (Fig. 5). 
Table 3: Conception rates of mares in $\mathbf{4}$ dietary groups.

\begin{tabular}{|c|c|c|c|c|c|c|c|}
\hline \multirow[t]{2}{*}{ Dietary group } & \multicolumn{6}{|c|}{ Oestrous period after parturition when mares were mated } & \multirow{2}{*}{$\begin{array}{l}\text { Mated oestrous period } \\
\text { per conception }\end{array}$} \\
\hline & $1 s t^{a}$ & 2nd & 3rd & 4th & 5th & 6th & \\
\hline 1 & $1(100 \%)^{b}$ & $5(80 \%)$ & $1(0 \%)$ & $1(0 \%)$ & - & - & 1.6 \\
\hline 2 & - & $3(33 \%)$ & $3(33 \%)$ & $2(50 \%)$ & $1(0 \%)$ & $1(100 \%)$ & 2.5 \\
\hline 3 & - & $4(100 \%)$ & - & - & - & - & 1.0 \\
\hline 4 & - & $5(100 \%)$ & - & - & - & - & 1.0 \\
\hline
\end{tabular}

${ }^{\mathrm{a}}$ Foal heat.

${ }^{\mathrm{b}}$ Number of mares (conception rate of mares mated during cycle).

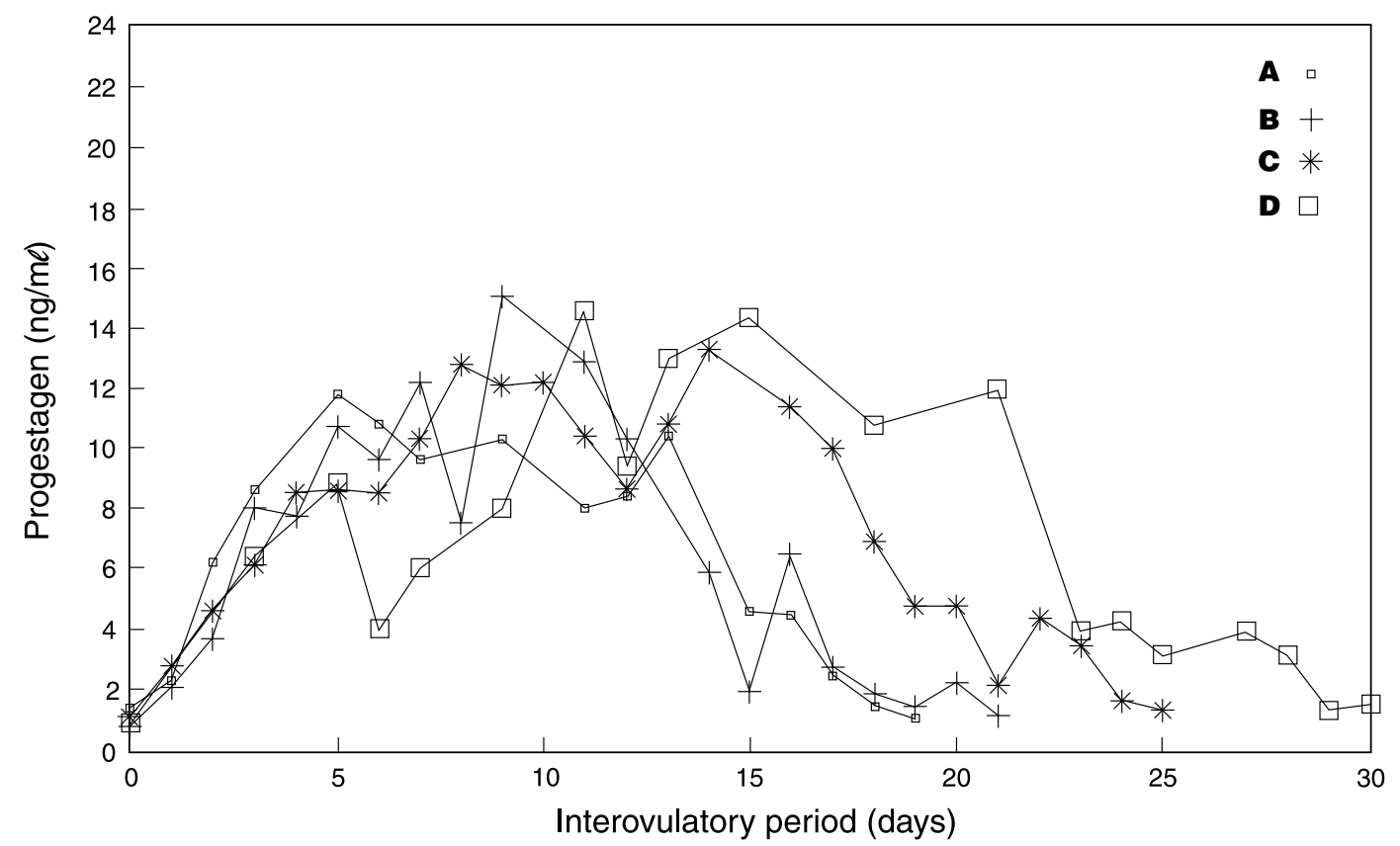

Fig. 2: Mean serum progestagen concentration $(\mathrm{ng} / \mathrm{ml})$ in mares with interovulatory periods of $(\mathbf{A}) \mathbf{1 7}-19 \mathbf{d}(\mathrm{n}=4)$, $(\mathbf{B}) \mathbf{2 0 - 2 2} \mathbf{d}(\mathrm{n}=5)$, (C) 24-25 d $(n=5)$ and (D) 29-30 d $(n=2)$ during the oestrous cycle following foal heat.

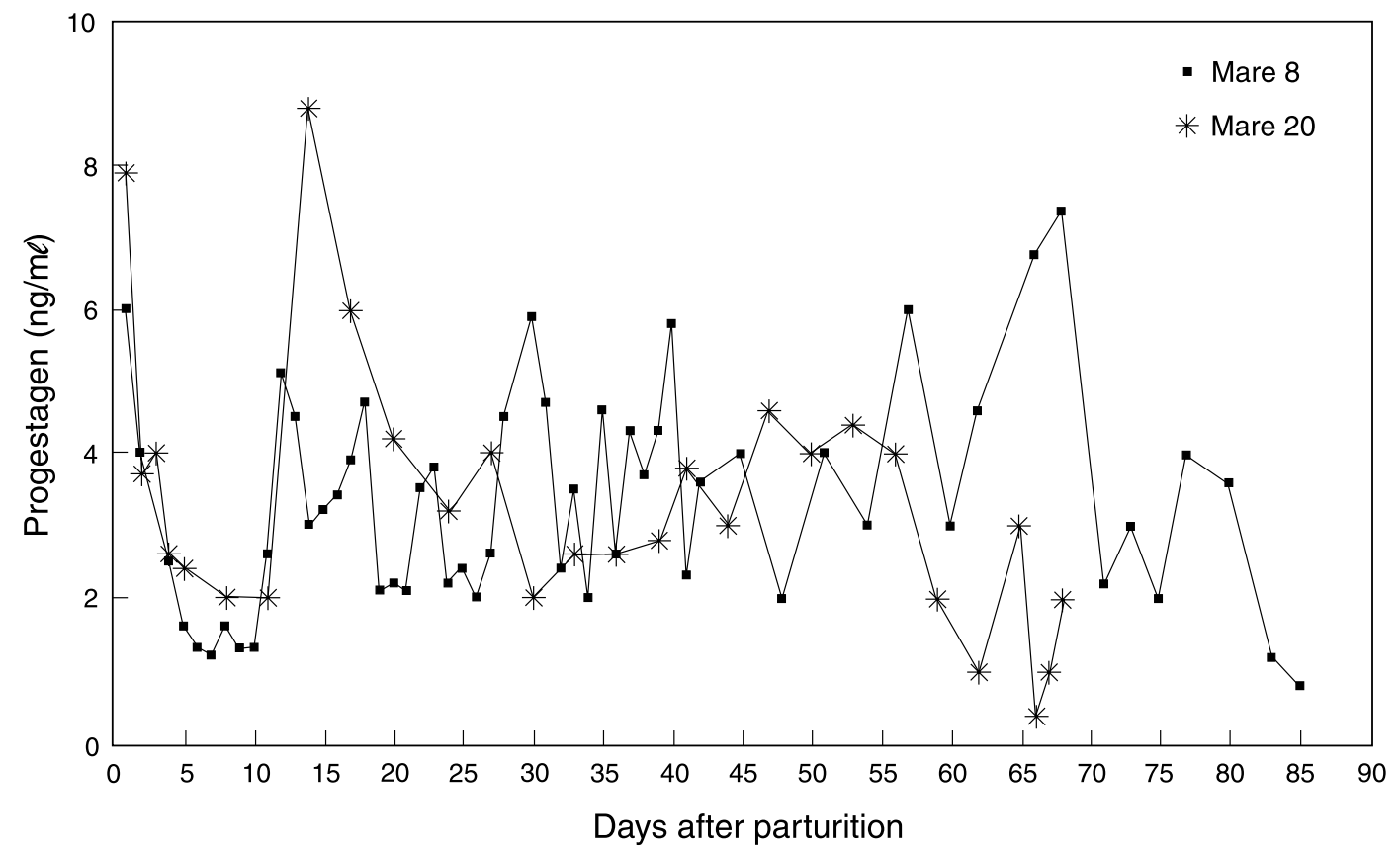

Fig. 3: Serum progestagen concentrations (ng/ml) of Mare 8 (Group 1) and Mare 20 (Group 4) that developed persistent corpora lutea after ovulation. 


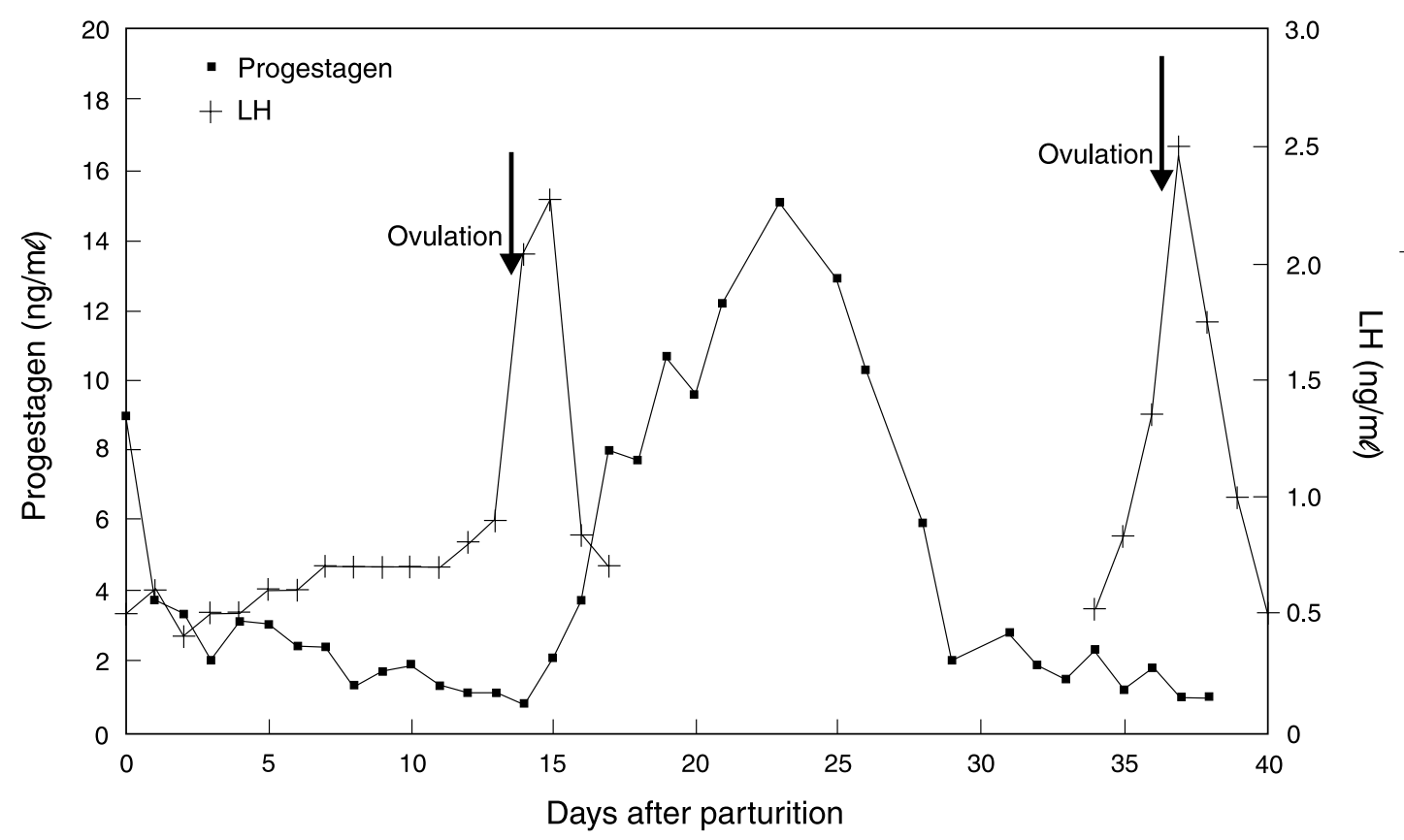

Fig. 4: Mean serum progestagen concentration $(n g / m l)$ of mares $(n=18)$ that ovulated at foal heat followed by a normal oestrous cycle.

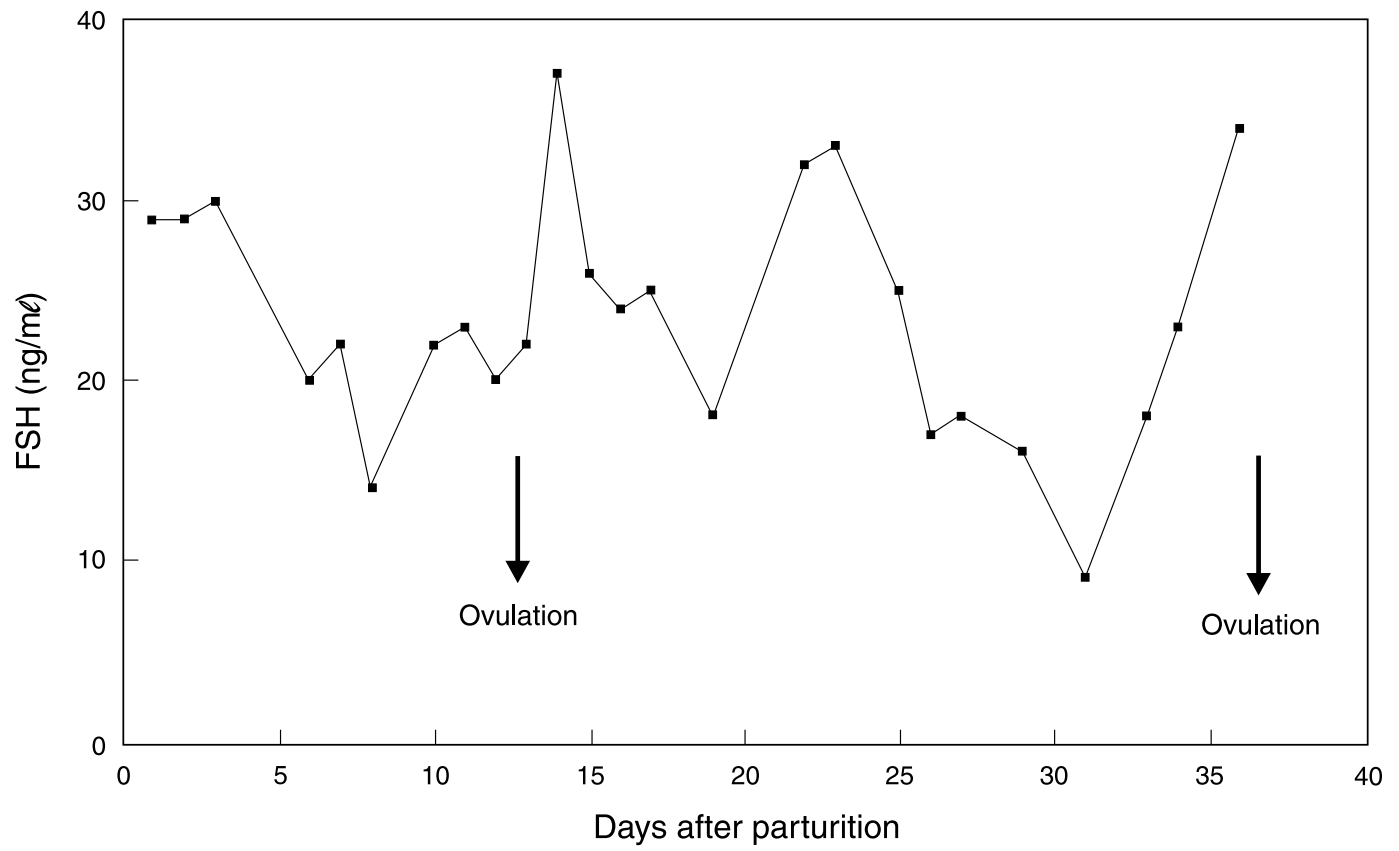

Fig. 5: Mean serum FSH concentration $(n g / m l)$ of mares $(n=18)$ that ovulated at foal heat followed by a normal oestrous cycle.

At parturition the mean FSH concentrations were relatively high $(25 \mathrm{ng} / \mathrm{ml})$ and increased $(30 \mathrm{ng} / \mathrm{m} \ell)$ during the 1 st 3 days post partum. In all mares that showed foal heat, FSH concentrations declined after Day 3 to reach minimum concentrations $(15 \mathrm{ng} / \mathrm{m} l)$ by Day 8 . The mean FSH concentrations increased at the onset of foal heat and reached high concentrations $(>30 \mathrm{ng} / \mathrm{m} l)$ the time of ovulation. Thereafter concentrations declined $1-2 \mathrm{~d}$ after ovulation to reach low values $(<20 \mathrm{ng} / \mathrm{m} \ell)$ 5-7 d after ovulation. An increase in FSH concentrations with maximum concentrations of approximately $33 \mathrm{ng} / \mathrm{m} \ell$ were found from Days 9-12 of the following cycle, after which the concentrations declined to minimum values $(<20 \mathrm{ng} / \mathrm{m} \ell)$ by Day 18 . Increases were recorded $2-3 \mathrm{~d}$ before the next ovulation (Fig. 5).

The conception rate of the lactating mares is shown in Table 3. Mares in
Groups 3 and 4 conceived at the 1 st mated oestrus period compared to the 1.6 (Group 1) and 2.5 (Group 2) mated oestrous periods per conception in the groups receiving the low-quality protein diets.

\section{DISCUSSION}

The total daily protein requirement of a mare with a body weight of $500 \mathrm{~kg}$ is 800 $870 \mathrm{~g} /$ day during late pregnancy and 
1284-1427 g during the 1st 3 months of lactation $^{20}$. In the current study the mean body weight of all the mares in the respective dietary groups was below $500 \mathrm{~kg}$ immediately after foaling. The total daily crude protein intake of the mares in the 4 dietary groups varied between 1000 and $1800 \mathrm{~g}$ /day during late pregnancy, while the lowest daily crude protein intake of $1200 \mathrm{~g}$ received by the mares in Group 1 during lactation is considered to meet their requirements ${ }^{35}$. It is thus clear that, according to the recommendations of the National Research Council, Washington $\mathrm{DC}^{20}$, none of the mares suffered from a protein deficiency during any stage of this trial.

Foal heat normally commences 7-12 d post partum $^{14,22}$. Although there was no significant difference in the number of days from parturition until the onset of foal heat between groups, the mean duration of this period for mares in Group 1 (low-quality protein) was $7 \mathrm{~d}$ compared to $10 \mathrm{~d}$ in Group 4 (high-quality protein). The 2 mares that showed the 1st signs of oestrus 80 and 64 days after foaling, foaled early during the season (transitional phase) and the prolonged post partum anoestrous periods were probably due to the effect of season/photoperiod and not protein nutrition. The effect of season on the incidence of foal heat has been described in Thoroughbred and Percheron mares ${ }^{30}$. A higher incidence of failure to show foal heat was found amongst mares that foaled during early spring and also amongst high milk producers $^{30}$. The pooled results (Table 2) indicated that the time of foaling (season) played an important role in the incidence of oestrus. In a previous study with barren mares kept in the same locality, only $10 \%$ of the mares ovulated between 29 August and 20 September, while $70 \%$ ovulated from the last week in September to midOctober $^{36}$. When the 2 mares described above are excluded, the current results are in agreement with the literature $e^{14,21,36}$. Protein nutrition apparently had very little effect on the duration of the period from parturition to the onset of foal heat in the mares used in this study.

The average duration of foal heat (Table 1) of $8.8 \mathrm{~d}$ for Group 1 (low-quality protein) was approximately $3-4 \mathrm{~d}$ longer than that recorded in any of the other groups. Mares in Group 1 ovulated on average $7.3 \mathrm{~d}$ after the onset of oestrus, approximately $3 \mathrm{~d}$ later than the mares in the other groups. However, when the number of days from parturition to ovulation is compared, no differences were found among groups (Table 1).

Table 1 shows that the duration of oestrous cycles following foal heat was 3-4 d longer in the fishmeal-supplemented Groups ( 3 and 4) than in Groups 1 and 2, which did not receive fishmeal.

In addition, the duration of the oestrous cycles in the mares in Groups 3 and 4 showed less variation (22-28 d) than mares in Groups 1 and 2, where a range of 13-31 days was recorded. This might indicate improved endocrine function with regard to the production of progesterone and possibly LH, which is important for early CL stimulation after ovulation. This is in agreement with previous results, where high-quality protein decreased the time to 1st ovulation after the anovulatory period in barren mares ${ }^{36,37}$. However, the mean duration of the oestrous cycles was $20.8 \mathrm{~d}$ (13-31), which compares favourably with the $20.7 \mathrm{~d}$ reported for Thoroughbred mares in the southern hemisphere ${ }^{30}$.

During late pregnancy and at parturition the brain-pituitary-ovarium (BPO) axis and the uterus are exposed to high circulating concentrations of progestagen, oestrogen, prostaglandins and oxytocin. After parturition, not only must the uterus recover, but also the BPO axis of the positive and negative endocrine feedback systems to enable resumption of the ovarian cycle ${ }^{32}$. Total serum progestagen concentrations did not differ between groups from parturition until the onset of foal heat. The relatively high total serum progestagen concentrations (5.2$16.4 \mathrm{ng} / \mathrm{ml}$ ) found on the day of parturition declined rapidly to concentrations of $2-3 \mathrm{ng} / \mathrm{m}$ l within the next $48 \mathrm{~h}$, which is in agreement with previous findings ${ }^{13,14}$. Although the effect of protein nutrition on progestagen concentration during the post partum period is uncertain, it appears that in the mares that only came into oestrus 15-19 d post partum the progestagen concentrations remained at between $1.5-3.0 \mathrm{ng} / \mathrm{ml}$ until $12-14$ days post partum. The possible suppression of GnRH secretion by this persistently elevated level of serum progestagen is unknown at this stage.

The serum progestagen secretion patterns as described and shown in Fig. 2 during the oestrous cycle following foal heat are in agreement with those described previously ${ }^{3,31}$. The mean serum progestagen concentrations of mares that exhibited interovulatory periods of $17-$ 19 d, 20-22 d, 24-25 d and 29-30 d (Fig. 2) indicate that, as the duration of the oestrous cycle increases, mid-cycle progestagen concentrations remain elevated for a longer period during the luteal phase of the cycle, and that maximum progestagen concentrations occur 2-3 d later during the oestrous cycle (Fig. 2). This might initially be the result of understimulation of the luteal tissue by $\mathrm{LH}$, leading to lower production of progesterone. Early embryonic loss before Day 12 has no prolonged effect on the duration of the oestrous cycle ${ }^{11}$.

The 2 mares that ovulated 6-11 days post partum and developed persistent corpora lutea only came into oestrus between 40-80 days after the 1st ovulation. Both mares foaled during the transitional period (August-September), at the time of the year when the incidence of ovulation amongst barren mares is reported to be low ${ }^{36}$. A similar decline in ovarian activity after parturition as well as ovulation during foal heat in mares that foaled during winter or early spring has been described $^{26}$. However, the results of this study indicate that the protein intake and quality had very little effect on progesterone production during the early post partum period.

No differences in the time of the $\mathrm{LH}$ peak secretion or the maximum concentration were found between dietary Groups 1 and 4 during ovulation at foal heat or during the following oestrous period. It is accepted that the photoperiod might have influenced LH secretion, as has been described ${ }^{37}$. Current results are in agreement with previous reports of low LH concentrations at parturition ${ }^{26}$. LH concentrations are reported to increase gradually from Day 6 post partum until 2 days before ovulation, followed by a sharp increase to reach peak concentrations just after ovulation ${ }^{26}$. As shown in Fig. 4, the increase in $\mathrm{LH}$ coincides with low progestagen concentrations at 4-6 days post partum. Serum oestrogen concentrations that increase 5-10 days post partum ${ }^{21}$ stimulate secretion of LH. According to the results of the individual mares in this study, the LH peak was recorded on the day of ovulation or the day following ovulation, which is in agreement with current literature ${ }^{26}$.

Although no differences in the concentrations of FSH were found among mares in the different dietary groups, the observed decrease in FSH concentrations after parturition and the subsequent increase before oestrus and ovulation during foal heat have been described previously ${ }^{14,26}$. It is evident from the results of the individual mares that a relationship exists between the time when FSH concentration begins to decline and the time of ovulation. It therefore indicates that in cases where foal heat is delayed, the typical FSH secretion pattern does not occur at the same early stage. A similar stimulatory effect of high-quality 
dietary protein on FSH production found in barren mares ${ }^{37}$ was not observed in this group of mares during the post partum period. The overriding effect of season/photoperiod over protein quality of the diet might have been the reason for this finding.

The 10-14-day cyclical secretion pattern of FSH found in the lactating mares in this study (Fig. 5) is in agreement with previous reports ${ }^{9,27,37}$. FSH stimulates follicular growth and a FSH peak normally occurs a few days after ovulation. Oestrogen produced by the developing follicles stimulates the LH surge and subsequently ovulation. In Equidae the mid-cycle FSH peak results in follicular development and the formation of midcycle follicles. These follicles generally undergo regression as $\mathrm{LH}$ concentrations, which increase slightly during this period but do not reach peak concentrations, are insufficient to stimulate follicular maturation and ovulation ${ }^{29}$.

Only $56 \%$ of the mares that were not supplemented with fishmeal (Groups 1 and 2) conceived when mated during the oestrous period following foal heat, compared to the $100 \%$ conception rate in the mares in Groups 3 and 4 (fishmeal supplemented). However, all mares mated in Groups 1 and 2 eventually conceived during subsequent oestrous periods.

\section{CONCLUSION}

Inclusion of high-quality protein in the diet of lactating mares resulted in an increased conception rate. The incidence of abnormally long or short oestrous cycles was reduced in mares receiving fishmeal supplementation. Serum progestagen, FSH and LH concentrations were unaffected by protein intake and quality. It would appear that the normal endocrine function of the brain-pituitaryovarian axis is resumed within 6-18 days post partum with the possible exception of mares foaling during early spring. The effect of season/photoperiod influenced the post partum breeding results of mares that foaled during early spring detrimentally. Uterine involution may be delayed in mares fed low-quality protein diets resulting in a decrease in conception rate, an increase in the number of services per conception and, more importantly, in Thoroughbreds an increased possibility of lowered pregnancy rates at the end of the restricted breeding season.

\section{ACKNOWLEDGEMENTS}

We thank Mr S W P Cloete, Elsenburg Agricultural Development Institute, for statistical analysis and the S A Medical Service for providing experimental animals and financial support.

\section{REFERENCES}

1. Achnelt E, Plas J 1947 Time of the first ovulation in mares after foaling. Animal Breeding Abstracts 15: 233

2. Alexander S L, Irvine C H G, Turner J E 1987 Comparison by three different radioimmuno assay systems of the polymorphism of plasma FSH in mares in various reproductive states. Journal of Reproduction and Fertility Supplement No. 35: 9-18

3. Allen W R 1987 Endocrinological and immunological aspects of pregnancy and pregnancy loss. Proceedings, 9th Bain Fallon Lectures Sydney: 61-74

4. Bain A M 1957 Estrus and infertility of the Thoroughbred mare in Australasia. Journal of the American Veterinary Medical Association 131: 179-185

5. Belonje PC, Van Niekerk C H 1975 A review of the influence of nutrition upon the oestrous cycle and early pregnancy in the mare. Journal of Reproduction and Fertility Supplement No. 23: 167-169

6. Deskur S 1965 The first oestrus and ovulation after parturition in the mare. Animal Breeding Abstracts 33: 533

7. Doreau M, Martin-Rosset W, Boulot S 1988 Energy requirements and the feeding of mares during lactation: review. Livestock Production Science 20: 53-68

8. Du Plessis J L 1964 Some observations and data in Thoroughbred breeding. Journal of the South African Veterinary Medical Association 35: 215-221

9. Evans M J, Irvine C H G 1975 Serum concentrations of FSH, LH and progesterone during the oestrous cycle and early pregnancy in the mare. Journal of Reproduction and Fertility Supplement No. 23: 193-200

10. Faure A S 1975 Vroeë embrionale verliese weens wanvoeding by Merinoskape. MSc thesis, University of Stellenbosch

11. Forde D, Keenan L, Wade J, O'Connor M, Roche J F 1987 Reproductive wastage in the mare and its relationship to progesterone in early pregnancy. Journal of Reproduction and Fertility Supplement No. 35: 493-495

12. Furr B J 1973 Radio-immunoassay of progesterone in peripheral plasma of the domestic fowl venous plasma. Acta Endocrinologica 72: 89-100

13. Ganjam V K, Kenny R M, Flickinger G 1975 Effect of exogenous progesterone on its endogenous levels: biological half-life of progesterone and lack of progesterone binding in mares. Journal of Reproduction and Fertility Supplement No. 23: 183-188

14. Ginther O J 1979 Reproductive biology of the mare. Basic and applied aspects. McNaughton and Gunn, Ann Arbor, Michigan

15. Harvey W R 1977 Users guide for LSML 76 mixed model least squares and maximum likelihood computer program. Ohio State University, Ohio

16. Henneke D R, Kreider J L 1979 Effects of restrictive suckling on post partum reproductive performance in mares. American Journal of Veterinary Research 40: 1281-1284

17. Henneke D R, Potter G D, Kreider J L 1981 Rebreeding efficiency in mares fed different levels of energy during late gestation. Proceedings, 7th Equine Nutrition Physiology Symposium. Virginia State University, Petersburg: 101-104

18. Holtan D W, Nett T M, Estergreen V L 1975 Plasma progestins in pregnant, post partum and cycling mares. Journal of Animal Science 40: 251-260

19. Matthews R G, Ropiha R T, Butterfield R M
1967 The phenomenon of foal heat in mares. Australian Veterinary Journal 43: 579-582

20. National Research Council 1989 Nutrient requirements of horses (5th revised edn). National Academy Press, Washington DC

21. Nett T M, Holtan D W, Estergreen V L 1975 Levels of LH, prolactin and oestrogens in the serum of post-partum mares. Journal of Reproduction and Fertility Supplement No. 23: 201-206

22. Nishikawa Y 1959 Studies on reproduction in horses. Japan Racing Association Minotoku, Tokyo

23. Niswender H D, Reichert L E, Midgley A R, Nalbandov A V 1969 Radio-immunoassay for bovine and ovine luteinizing hormone. Endocrinology 84: 1166

24. Odell W D, Abraham G A, Skowsky W R, Hescox M A, Fisher D A 1971 Production of antisera for radio-immunoassays. In Odel W D, Daughaday W H (eds) Principles of competitive protein binding assays. J B Lippencott \& Co, Philadelphia: 57-76

25. Pagan J D, Hintz H F, Rounsaville T R 1984 The digestible energy requirements of lactating pony mares. Journal of Animal Science 58: 1382-1387

26. Palmer E, Draincourt M A 1983 Some interactions of season of foaling, photoperiod and ovarian activity in the equine. Livestock Production Science 10: 197-210

27. Pineda M H, Ginther O J 1972 Inhibition of estrus and ovulation in mares treated with an antiserum against an equine pituitary fraction. American Journal of Veterinary Research 33: 1775-1780

28. Tolksdorff E, Jochle W, Lamond D R, Klug E, Merkt H 1976 Induction of ovulation during the post-partum period in the Thoroughbred mare with a prostaglandin analogue synchrocept. Theriogenology 6: 403-412

29. Vandeplassche M, Henry M, Coryn M 1979 The mature mid-cycle follicle in the mare. Journal of Reproduction and Fertility Supplement No. 27: 157-162

30. Van Niekerk C H 1965 The breeding cycle, ovarian changes and tubal sojourn of ova in the mare. M Med Vet thesis, University of Pretoria

31. Van Niekerk C H 1973 Morphology and physiological changes in the genital system of mares. DVSc thesis, University of Pretoria

32. Van Niekerk C H 1976 Limitations to female reproductive efficiency. In G J Tomes, D E Robertson, R J Lightfoot (eds) Proceedings of the International Congress on Sheep Breeding, Perth, Australia, August 1976: 294-309

33. Van Niekerk C H, Morgenthal J C 1982 Fetal loss and the effect of stress on plasma progestagen levels in pregnant Thoroughbred mares. Journal of Reproduction and Fertility Supplement No. 32: 453-457

34. Van Niekerk F E, Van Niekerk C H 1997 The effect of dietary protein on reproduction in the mare. I. The composition and evaluation of the digestibility of dietary protein from different sources. Journal of the South African Veterinary Association 68: 78-80

35. Van Niekerk F E, Van Niekerk C H 1997 The effect of dietary protein on reproduction in the mare. II. Growth of foals, body mass of mares and serum protein concentrations of mares during the anovulatory, transitional and pregnant periods. Journal of the South African Veterinary Association 68: 81-85

36. Van Niekerk F E, Van Niekerk C H 1997 The effect of dietary protein on reproduction in the mare. III. Ovarian and uterine changes 
during the anovulatory, transitional and ovulatory periods in the non-pregnant mare. Journal of the South African Veterinary Association 68: 86-92

37. Van Niekerk F E, Van Niekerk C H 1997 The effect of dietary protein on reproduction in the mare. IV. The serum progestagen, FSH, $\mathrm{LH}$ and melatonin concentrations of non- pregnant mares during the anovulatory and transitional periods. Journal of the South African Veterinary Association 68: 114-120

38. Van Niekerk C H, Van Heerden J S 1972 Nutrition and ovarian activity of mares early in the breeding season. Journal of the South African Veterinary Association 43: 355360
39. Visser J H 1991 'n Geslagsendokrinologiese ondersoek na die seisoenaliteit van ramme van vyf verskillende skaap- en bokrasse. MSc thesis, University of Stellenbosch

40. Yousefnajadian E, Florensa E, Collins W P, Sommerville I F 1972 Radio-immunoassay of plasma progesterone. Journal of Steroid Biochemistry 3: 893 